\title{
Overview of concluding discussion
}

The symposium with which the present issue of SCE is concerned concluded with a frank and probing discussion about the future of theological ethics. ${ }^{1}$ It is the purpose of this final contribution to provide a sense of the character of that debate and to reflect upon its significance. ${ }^{2}$

\section{The state of the discipline}

A central thread of the discussion attempted to assess the current state of the discipline of theological ethics within the university and to consider its future. Susan Parsons, speaking as the editor of this journal, made a series of observations which drew widespread support. She began her reflections by noting the shifts in institutional structures which are influencing the discipline. She noted particularly the way in which disciplines are increasingly being forced to understand themselves in terms of crude utilitarian measures_-reorganising their inquiries around 'impact' and 'commercial efficacy'. She noted likewise that disciplines are being pressed into flattened structures without any higher discipline or principle to organise how various enquiries relate to one another. With respect to theological ethics itself, she expressed a certain frustration with what she perceives as troubling trends in the quality of submissions received by the journal. As she suggested, whilst the movement to a more regulated academic blogosphere may well turn out to be a healthy development for theological inquiry, there remains a place for journals which are hard-copy and peer-reviewed in order to preserve a goldstandard of high quality research. She noted particularly the way in which submissions from many younger scholars were failing, on the one hand, to display any sort of sophisticated comprehension of the provenance of ideas and, on the other, to proffer positions that are marked by their originality. Instead, she sees a trend to focus upon advocating for particular (often tired) factional positions. These

\footnotetext{
${ }^{1}$ Joshua Hordern gratefully acknowledges the generous support of the Sir Halley Stewart Trust which has enabled him to prepare this paper for publication.

${ }^{2}$ The present work is focused exclusively upon summarising the discussion that occurred and, whilst it attempts to draw out the complexities of various comments, it does not attempt to interact critically with them.
} 
developments are worrying for Parsons because, as she said, theological ethics should take us to the edge- one must attempt to go as far as possible intellectually in the quest to be touched by the divine.

This overall analysis seemed to resonate with postgraduate students attending the discussion who had particularly highlighted the challenge to the intellectual formation of students which this overall situation presented. Notwithstanding Michael Sherwin's observation that the most important formation had already taken place before students arrived at university (a reality which placed great responsibility on churches in particular) postgraduates were concerned to emphasise the importance for the long-term future of the discipline of careful attention to student formation in the present. Dr Parsons strongly supported this view by emphasising that the sharpest submissions to the journal often came from post-graduate students. Oliver O’Donovan, having warmly endorsed the importance of the journal to the discipline of theological ethics, further analysed the contemporary situation by exploring the internal moral condition of universities in general and theology in that context. He observed that the 'future' has not yet been determined--much to the frustration of over-zealous, procedural university bureaucracies. Whatever such authorities, or indeed we ourselves predict, the future will stubbornly refuse to correspond. O'Donovan observed the tendency in universities today to project often incompatible scenarios into the future leading to fierce competition accompanied by wild and unrealistic boasting. When the emptiness of these boasts come to light, there follows a complete crisis of self-belief and mission. This cycle is commonly repeated across higher education institutions.

Despite this somewhat bleak outlook, both Oliver O’Donovan and Susan Parsons were hopeful about the future. Dr Parsons saw the conference itself as excellence at work, a strong sign of the ongoing vitality of the discipline. For O'Donovan, the open future is an invitation for more focussed reflection. The conference would be helpful, he emphasised, if it enables us to see what we should be doing next. As regards the further future, what is required is not speculative prediction. Rather we first need prudence to see inside an act and understand its ability to lead somewhere, to see what will unfold if we are successful in following a certain course. And second we need hope itself, rooted in an affirmation about God and God's promises (or at least an affirmation about history), which makes prudential considerations intelligible and worthwhile. The ever-present threat is the absorption of such 
theological hope into antithetical institutional logics which tempt academics to pursue immediate influence only, abandoning long-term vision and so ending up merely ensuring that salaries keep getting paid. This was not to decry immediate influence or attention to pressing issues but rather to say that intellectual investment in, for example, ecology, economics or bioethics, must have the moral wherewithal to say 'no' to the temptation of quick fixes. Contra the apparent flattening of the disciplines, theology has just this capacity to keep vision alive amidst the mighty forces of bureaucratization.

The interrelation of theology with other disciplines in the contemporary university was a recurring theme. Lisa Cahill, Michael Banner and Jonathan Chaplin in various ways urged greater attention to the form of interaction with the social sciences. For Lisa Cahill, attention to human and indeed natural sciences is vital to examining whether gender differences are constructed or innate, an enquiry which has significance for the tasks of textual interpretation, retrieval and re-appropriation, tasks which feminist theology is peculiarly well-equipped to sustain because of its capacity to explore the prideful tendency of male perspectives to dominate in academic thinking, the domestic sphere and the labour market. Michael Banner's interest lay more in the opportunities afforded by social anthropology to attend to 'everyday ethics' such as those displayed by the parents of the children affected by the Alder Hey Hospital scandal (which concerned the removal and withholding of dead children's tissue without parental consent). Banner commented on the opacity of official ethical discourse to the worldview of the parents involved and the corresponding importance of articulating that specific inner worldview. Such everyday ethics could best be understood and responded to by academics both engaging in social anthropology and being closely involved with public decision-making bodies such as the Human Tissue Authority with whom Banner has worked. Jonathan Chaplin further commended extensive dialogue with social science disciplines arguing for a certain dependence of theological ethics' upon the social sciences in the development of its own thinking. Sarah Coakley affirmed this but noted that, for this to be a viable research area, senior academics had to blaze the trail in order to invite postgraduate researchers to join in. This consensus was, however, qualified by Joan Lockwood O'Donovan who observed a profound malaise in the human sciences since they routinely 
fail to consider themselves to be also moral or philosophical sciences. On this view, social science's disguise of normative advocacy as scientific description is a crucial place of contest within the contemporary university to which theological ethics should be especially alert. As regards the relation of theology and the natural sciences, John Hare first noted the tendency of contemporary theologians to think too much about theology at the expense of actually getting on and doing theology and second argued for a detailed moral theological engagement with the profound cultural and societal uncertainties stemming from evolutionary theory. There was general agreement as to the importance of this apologetic task for theological ethics but outstanding uncertainty about the shape of such a conversation in light of the variety of forms of evolutionary theory. (Following this particular lead, the 2012 Cambridge McDonald conference will pursue the theme of 'Evolution and Theological Ethics'.)

\section{The task of the discipline}

These considerations about the state of the discipline within the university ran concurrent to the specific conceptual question which occupied much of the morning's discussion, namely the future of Christian theological ethics as it engages with critical voices from the outside. There was a shared conviction that the Christian ethicist's first commitment is to the importance and beauty of the internal structure of Christian faith and practice. From this shared conviction, a debate followed which crystallised around two questions: A. how is such internal practice related to articulation and rational description/justification? B. what is the relationship between the internal coherence of such practice and the external appeal of Christianity? For those who share the conviction that Christian ethics is centrally dependent upon the formative and liturgical practices of the Christian tradition, a set of questions arise regarding the relationship between practice and theory, activity and articulation. As will become clear these questions are not simply matters of justifying such practices before sceptical audiences, but are also of crucial importance for the internal coherence of such practices themselves.

The clearest articulation of these questions came in the form of a series of sophisticated challenges offered by Raymond Geuss. As an outsider, Geuss argued that theological ethicists must 
take the diversity of their own practices with great seriousness for it just this diversity that suggests critical questions regarding the nature of the reality to which Christianity (or any other religion for that matter) is committed. That diversity exists not merely in theory but in religious practice is important for Geuss. Alongside Christian practices, he cited especially Islamic legal practices and diverse forms of public worship in every religion. One may well claim, he argued, that practices generate things of great value (by consolidating individual and group identity for example), and so they do. Yet, just because they generate solid identity this does not fully justify them. Not all practices are good. Here Geuss pushed the theological ethicist to take seriously the responsibility to truth that comes with being a theologian. On Geuss's understanding, “Theology is not just the development of certain practices. To call it theology is to give a certain interpretation of it. Not just 'read the Bible every day' but 'I read the Bible every day because..."' One could, of course, deny this position holding that the theological ethicist is merely concerned with describing religious practice. To hold this, however, would be to concede much of the basis upon which such a theologian could argue that there is something of unique value in this or that practice. To push this descriptivist line too far, in other words, would be to give up on the commitment to the internal coherence and beauty of Christian faith. Indeed, Geuss went further to suggest that religious practices without theology are unlikely to be sustainable for long. According to Geuss, however, if one upholds theology's commitment to arguing for truth in one way or another one will encounter two difficulties. The first arises out of the diversity of such 'value-laden projects'. For if there does exist true incompatibility between the practices of those who consider themselves to be closely allied, then this must in some sense call the claims to truth arising from those practices into question. The second regards not merely how one will confront the internal diversity of practice, but also how one will engage with external voices. What is needed, here, is not merely internal explication of the practices. If religion is not merely about being a source of important things, but about offering a more robust vision of reality then what is needed is not just a description of the grammar of a given practice but an ability to engage constructively, and at times combatively, with those beyond one's boundaries. 
Whilst it was not possible for participants to offer sustained responses to Geuss's challenges within the confines of the discussion a series of potential options were considered. One set of comments constellated around the idea that the very question of the relationship between practice and theory which was implicit within Geuss's critique of the state of theological ethics is itself a kind of diagnosis of the historical situation in which the discipline finds itself. Susan Parsons, for example, suggested that it manifests the divorce between the practices of prayer (lex orandi) and those of the intellect (lex credendi) a divorce which itself reflects the climate in which theological ethics is now taking place--be that the institutional climate (i.e. a university that works with a flattened professionalised view of disciplinary structure) or societal (which, as Robin Lovin emphasised, has undergone an increasing 'simplification' in recent decades). ${ }^{3}$ This is not to pass the responsibility onwards, but rather to attempt to be more attentive to the actualities of our time. Such comments do not yet respond to Geuss's challenges so much as suggesting that if one is to respond one must begin by becoming aware of the history of the ailment.

Some participants responded more directly to one or more of the challenges. Joan Lockwood O'Donovan, for example, addressed both difficulties by holding that some practices are more logocentric than others having in mind particularly the community's interaction with scripture. Interaction with Scripture, she argued, is not merely one practice alongside others, but is itself privileged because it is able to serve as an informing activity by which the diversity of other practices are able to meet an 'objective horizon of meaning'. On this view, then, there is not a problem of variation in practices for one practice and one authority chastens and directs the others. For O'Donovan, Scripture is universal in its authority not only with respect to internal Christian practices but also with respect to humanity more broadly.

Another way of responding particularly to the latter challenge, cogently defended by Hans Ulrich and Lisa Cahill, was to focus more closely on the robust albeit implicit theology hidden within religious practice. On this view, whilst an important task of the theological ethicist is to unfold that

\footnotetext{
${ }^{3}$ The point here seemed to be that the public discourses that we trust to respond to extremely complex societal challenges have, on Lovin's view, increasingly learned to rely upon brute and unsophisticated analyses which then lead to destructive and rash activity.
} 
theology so that it can be articulated more explicitly, the emphasis must still rest upon the internal beauty and cogency of the practice. The Christian ethicist must, in other words, be centrally concerned with recognising and fostering the internal beauty of the Christian community both for its own sake and because it is only in so doing that the resources for external engagement can be properly developed. Emphasis would then fall upon the idea of allure for the most powerful way to draw the outsider in is by confronting them with the beauty of the community. Indeed, for Oliver O'Donovan, the encounter with the beautiful is paradigmatic for every kind of recognition.

Hans Ulrich particularly emphasised that opening the 'grammar' of the Christian worshipping community's practices was the very way to deepen external interaction since this opening invites the challenges which will come from other grammars. To talk about grammar is then already to be on the road to talking about the 'more' of apologetic conversation. This is especially so when considering Scripture which, he argued, is the essential basis for conceiving the future of theological ethics rightly. Sarah Coakley commented that it was this deep engagement in one's own practices that enabled the development of sympathy for other people's. This sympathy was reflected in Geuss' encouragement of philosophers and theologians to aspire to develop a sophisticated capacity to appreciate second-hand other people's first-hand valuations. Geuss illustrated this by referring to his own attempt to understand why his brother-in-law derives some value from sport, an interest which Geuss himself does not share.

Nigel Biggar, whilst in partial agreement with the emphasis on allure, felt that more was needed. Here he echoed Geuss's argument that explicating the internal logic of a practice, whilst important, is not the same as engaging with external voices through rational argument. For Biggar, then, one of the primary tasks for the future is to reflect critically upon Christian practices and commitments so as to test and consolidate them, thereby contributing to the growth of Christian communities. For, as Cahill emphasised, many or most are drawn into Christian faith by the beauty of the Christian life, not by technical arguments. Nonetheless, Biggar argued, it is important that when Simon Blackburn suggests that Christian ethics are ridiculous, or Geuss asks what contribution is made by the inclusion of God in religious practice, Christians should have some way to respond. Biggar argued that such a form of 
argument is important for five reasons. (i) Atheists are also children of God and should be given a proper response. (ii) Even uneducated people are rational beings who care about truth and deserve answers. (iii) Arguments may not be decisive, but they can play an important role in reforming not merely minds, but hearts and in removing rational obstacles to people's participation in practices. (iv) Atheist philosophers and scientists do actually prevail in certain important areas of contemporary society. This cultural predominance makes it more difficult for people who might affirm religious convictions in public and such people should be helped. (v) Christians are not the only ones to display moral virtue. But the question of why people should join the church rather than (or in addition to) Oxfam leads directly to the question of whether the beliefs that inform practices are true. These questions deserve an answer.

The difference between these two ways of responding to Geuss is not, in one sense, particularly stark. For the former (Cahill and Ulrich) does not seem to be rejecting either the apologetic task or the centrality of rational articulation for theological ethics; nor does the latter (Biggar) suggest that theological ethics should proceed in a fashion dictated by rational deliberation disconnected from the communal structures of Christianity. Indeed, both appear to be indebted to the idea that it is first and foremost the virtuous who have been trained up within the tradition to the fullest extent that are likewise able to interact with external critics most effectively. There is, however, still an important difference regarding not merely how one goes about the apologetic task, but also the relationship between reason and practice. For Biggar, one must not be merely concerned with strengthening the internal structure of Christian practice but must, rather, take on a more evaluative role so that one might, on the one hand, test the validity of such practices and, on the other, engage with secular moral philosophers. The latter activity requires one to know a great deal about both secular ethics and theological ethics so as to craft subtle apologetic tools fashioned for argumentative engagement with secular critics. Notice, however, that on this account the tools for rational evaluation and apologetic engagement are only accessible through some (however slight) abstraction from the practice itself. The position exemplified by Cahill and Ulrich, however, pushes one in the opposite direction encouraging the ethicist not to abstract 
herself from the practice, but rather to inhabit ever more deeply the logos embedded within the practice itself both for its own sake and for the sake of the apologetic task.

These dilemmas regarding the how the inner life of Christianity should relate to external voices led naturally into consideration of which voices should be engaged. Josh Hordern, for example, applauded the idea that Christian ethicists should be fostering robust theological and text-based conversation with other religious traditions, but wondered how to make decisions about which other traditions ought to be at the centre of one's efforts in this regard. He emphasised likewise the importance of understanding the structure of the challenges to be confronted when two traditions interact which do not share the same authorities. An important interchange between Joan Lockwood O’Donovan, Anver Emon and Robert Gibbs illustrated this point. Emon and Gibbs critiqued an easy Christian assumption that ethics are not about legalities, observing that law and jurisprudence were immensely important for Jewish and Islamic ethics and formed the essential points of engagement between Christians, Muslims and Jews. O’Donovan, while noting that such scholarship went very well with public policy considerations, emphasised that in the Christian tradition, law could not be divorced from love and that this directly shaped the form of Christian inter-religious and public engagement. A similar note had been struck earlier in the discussion when Sarah Coakley's encouragement of feminist theologies to engage more deeply with feminist philosophy in order to overcome a besetting antiintellectualism prompted Daniel Weiss to observe an interesting parallel between the way that feminist critique may illuminate theological blind spots and the way that alternative religions may do the same for each other.

On this topic, Anver Emon suggested that difficulties arise from the question of who occupies the public sphere. On his view, interaction between religious traditions is happening not so much because of some abstract conviction regarding the appropriateness of the activity, but rather because of genuine practical concerns regarding how to live together in a shared 'space'. Such conversations should not occur in the first instance only when debates about government policy arise, for, he suggested, in such contexts the genuine internal concerns of such traditions tend to be instrumentalised. Rather, Emon suggested that the conversations should happen primarily in the realm 
of a robust civil society. This raised the important question of how theology operates amidst deep pluralism where different authorities, modes of law and religious traditions are at work.

Whilst most of the participants seemed to agree with the emphasis upon civil society, Biggar expressed a more positive evaluation of interaction with government. Whilst he agreed that there are reasons to be suspicious and to 'keep your wits about you' he also expressed a sympathy with those who govern, noting that they tend to have genuine public-spiritedness. He argued that the problem is not so much lack of moral seriousness so much as genuine practical constraints on their time which limit them from being able to deliberate as carefully as possible. Thus, he argued, there is real opportunity for academics to play various constructive roles, highlighting in particular the way that academics can offer courage to those who are intimidated about expressing their convictions. He argued that the best way to go about playing this role is to develop patterns of candour and responsibility amidst long term friendship between academics and those in positions of power.

As we conclude, it is worth returning to a theme that was present (both explicitly and implicitly) throughout the conversation: the need for the future of the discipline to be undergirded by carefully developed practices of formation. Formation in any discipline depends on the discipline's history of engagement with reality. It is, after all, this history which shapes any discipline's characteristic modes of enquiry, practice and discourse. The point that was particularly emphasised in the conversation under consideration here, however, was that formation also depends upon developed practices of 'combat' with other (disciplinary and religious) traditions. Formation in Christian theological ethics, that is requires what David Burrell has described as "dialectical exchange between historically developed positions as a way of sharpening one's capacities for assessment by pitting them against formidable peers." Combat will be robust no doubt but combat should also be 'amiable' in the sense that scholars in the field of theological ethics must learn to play host to those enquiring into their own traditions and to be hosted in their turn. If ethics is substantially the task of being appropriately responsive to reality, then the process of formation must be centrally concerned with developing the capacity to perceive reality in all of its particularity. As became apparent here, since all inhabit a single reality, a crucial way to develop

\footnotetext{
${ }^{4}$ Burrell, David. Faith and Freedom: An Interfaith Perspective. Oxford: Blackwell, 2004, p.105.
} 
such a capacity is to engage in such contestations between sophisticated historically developed traditions of inquiry. 